\title{
The Effect of Pre-admission Hydroxychloroquine Treatment on COVID-19-Related Intensive Care Follow-up in Geriatric Patients
}

\author{
Fulya Çiyiltepe, ${ }^{1}$ (1) Ayten Saracoglu, ${ }^{2}$ (1) Yeliz Bilir, \\ (1) Elif Bombacı, ${ }^{1}$ (1) Kemal Saracoglu ${ }^{1}$
}

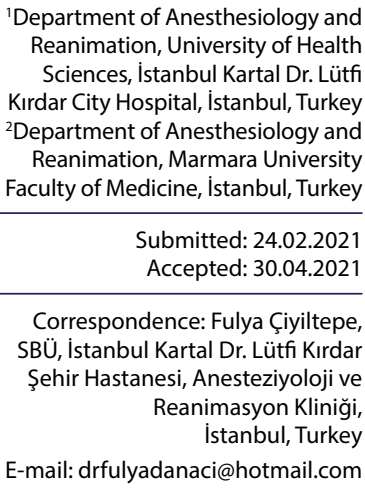

'Department of Anesthesiology and Reanimation, University of Health Sciences, İstanbul Kartal Dr. Lütfi Kırdar City Hospital, İstanbul, Turkey 2Department of Anesthesiology and Reanimation, Marmara University Faculty of Medicine, İstanbul, Turkey

Submitted: 24.02.2021 Accepted: 30.04.2021

Correspondence: Fulya Çiyiltepe SBÜ, İstanbul Kartal Dr. Lütfi Kırdar Şehir Hastanesi, Anesteziyoloji ve Reanimasyon Kliniği, İstanbul, Turkey E-mail: drfulyadanaci@hotmail.com

apspars

Keywords:

Coronavirus; geriatrics; hydroxychloroquine; intensive care units; mortality.

This work is licensed under a Creative Common Attribution-NonCommercial 4.0 International License.

\begin{abstract}
Objective: The admission rates to intensive care units and mortalities in geriatric patients are higher than the rest of the population with COVID-19 infection. Although the efficacy of hydroxychloroquine sulfate has been recognized, especially when started early during infection, its effectiveness at these early time points in geriatric patients has not been investigated. In this study, our primary aim was to investigate the effects of early treatment of hydroxychloroquine sulfate on COVID-19 positive geriatric patients, according to their clinical symptoms, situation before the intensive care, and patient survival.
\end{abstract}

Methods: A total of I47 geriatric patients diagnosed with COVID-19 in the intensive care unit were divided into three groups: Patients who were admitted to the intensive care unit from the emergency department but did not receive treatment (Group I); from the service for whose a 5-day treatment was initiated but not completed (Group 2); and those who completed 5-days of drug therapy (Group 3).

Results: Although demographic data were similar between the three groups, the age parameters were significantly differed between them. Furthermore, there was no difference between the groups regarding mortality rate, discharge time, or extubation. The time to mortality and the duration of mechanical ventilation were found to be significantly shorter in Group I $(p=0.00 I)$.

Conclusion: No significant effect was observed on patient survival and outcome due to early administration of hydroxychloroquine sulfate.According to our main findings, this study cannot recommend pre-admission hydroxychloroquine treatment for critically ill geriatric patients with COVID-19.

\section{INTRODUCTION}

The structure of coronaviruses reveals an enveloped, single-stranded sense RNA genome, and in particular, the SARS-CoV-2 virus, a member of this family, is the causative agent of COVID-19.[1] In December 2019, the first case of SARS-CoV-2 infection was confirmed in Wuhan, China, leading to an outbreak that was declared a pandemic by the World Health Organization (WHO) shortly thereafter. ${ }^{[2]}$

Geriatric patients are generally more susceptible to severe diseases than the rest of the population and have a higher admission to intensive care units (ICUs). ${ }^{[3]}$ Furthermore, mortality rates are also higher in the elderly and in patients over 65 years of age, where severe lung infection, acute respiratory distress syndrome (ARDS), and respiratory failure may result in death despite artificial ventilation. It has recently been reported that COVID-19 is a severe respiratory infection and mortality is higher in patients aged over 60 years, ${ }^{[4]}$ and approximately half of h COVID-19 patients over 80 years of age have died. ${ }^{[5]}$ During the COVID-19 pandemic, both in Italy and China, higher mortality rates were observed in the frail, elderly population with concomitant diseases. ${ }^{[6]}$ It is a well-known fact that immunity decreases with age and that COVID-19 infections can more easily reach the respiratory system in the elderly. ${ }^{[7]}$ Therefore, due to their high mortality risks, there is an urgent need for early diagnosis with swabs or early blood tests, and it is essential to start treatment as soon as possible. 
An international study including 7,500 physicians from 30 countries has shown that most of the physicians questioned considered hydroxychloroquine (HCQ) the most effective treatment for COVID-19. ${ }^{[8,9]}$ In vitro studies have shown that HCQ sulfate can indeed inhibit SARS-CoV-2 infection, ${ }^{[10,11]}$ while a separate in vitro study reported that the combination of azithromycin and HCQ inhibited SARSCoV-2 infection. ${ }^{\left[{ }^{[2]}\right.}$ Although the efficacy of this treatment has been accepted, especially when it is started in the early stages of the disease, the efficacy of early treatment has not been investigated in the geriatric population with high mortality rates. In this study, our primary aim was to investigate the effects of early treatment, which begins with the appearance of clinical symptoms before intensive care, on patient survivalin COVID-19 positive geriatric patients.

\section{MATERIALS AND METHODS}

Following approval by our ethics committee (Protocol no: $2020 / 5|4 /| 8|/| 6$, Date: 08/07/2020), the data of geriatric patients admitted to our ICU with the diagnosis of COVID-I 9 between April I and August I, 2020, were analyzed retrospectively. In line with the definition given by WHO, we defined the geriatric population as 65 years and older. $^{[13,14]}$

\section{Organization at the hospital}

On March II, 2020, all patients who could be safely discharged from our hospital were taken, and a special inpatient service was created for COVID-19 patients. In this way, we created the capacity to treat 500 patients in 31 clinics, with a further 10 policlinics established for COVID-19 patients. In total, 75,993 patients underwent PCR testing, 7,922 positive results, and $70 \mathrm{ICU}$ beds have been reserved for COVID-19 patients and 503 patients were admitted to the ICU since I August. Critically ill patients in need of intensive care were admitted from the emergency and inpatient services.

\section{Patient selection}

Patients were admitted to our ICU from both the COVID-19 services and the emergency department. The patients were divided into three groups: Group I $(n=52)$ included patients admitted to the ICU from the emergency department, who had been diagnosed with COVID-19 at least 5 -days ago but had not received treatment. Group $2(n=4 I)$ consisted of geriatric patients admitted from the COVID-19 ward and started 5-day treatment after clinical findings but were not completed within the scope of the first treatment protocol recommended by the Ministry of Health. Group $3(n=54)$ comprised of patients who completed 5-days of combined drug therapy. According to the treatment protocol recommended by the Ministry of Health, HCQ was administered at a loading dose of 800 $\mathrm{mg}$ on the first day followed by a maintenance dose of $200 \mathrm{mg}$ twice daily for five days. In the ICU, the 5-day treatment with HCQ was completed for the patients in the Group I. All patients received Favipiravir and their regimens were $3,200 \mathrm{mg}$ oral loading dose and then a I,600 $\mathrm{mg}$ dose every 12 hours on day I, followed by $600 \mathrm{mg}$ twice daily for 5 days. ${ }^{[15]}$

Patients who failed to start the possible treatment regimens due to contraindications, or those who died before the treatment regimen was started in the pre-intensive care clinics were excluded from the study. Patients who received the treatment regimen for at least 5 days at the clinics and who required tto be followed up in the ICU after their first-line therapy was completed, were included in the study. Patient comorbidities, thoracic computed tomography (CT) scores, time from admission to ICU to intubation, and extubation (in hours), mortality rates in the ICU, and the discharge time from the ICU (in hours) were all recorded.

\section{Assessment of computed tomography images}

All CT scans SARS-CoV-2 associated pneumonia were performed with three scanners (128-section Philips Ingenuity, 16-section Toshiba Alexion) in the absence of contrast material. The main scanning protocol was as follows: tube voltage, $120 \mathrm{kV}$; tube current modulation, 120 $\mathrm{mA}-380 \mathrm{~mA}$; detector configuration, $64 \times 0.625 \mathrm{~mm}$, or $16 \times 0.625 \mathrm{~mm}$; rotation time, $0.5-0.7 \mathrm{~s}$; slice thickness, 5 $\mathrm{mm}$; and pitch, 0.984 . The reconstruction kernel was lung with a $0,625 \mathrm{~mm}$ thickness and interval. All images were viewed at both lung (width, $1200 \mathrm{HU}$; level, $-700 \mathrm{HU}$ ) and mediastinal (width, $350 \mathrm{HU}$; level, $40 \mathrm{HU}$ ) settings. The images were interpreted using the lung window setting. ${ }^{[6]}$

Less than $50 \%$ of thoracic tomography involvement was defined as a mild disease and more than $50 \%$ as moderate to severe disease.

\section{Statistical analysis}

Statistical analyses were carried out using IBM SPSS Statistics 22. A one-way ANOVA test was employed for numerical data conforming to the normal distribution, while the Kruskal-Wallis $\mathrm{H}$ test was applied in cases where there was no normal distribution. For intra-group analyses, a post-hoc test was used for analysis of normally distributed data and the Mann-Whitney $U$ test for non-normal distributions, and categorical groups were compared by chi-square test. The Kaplan-Meier test was performed to evaluate cumulative survival analysis. The results were evaluated with a $95 \%$ confidence interval, and therefore, $\mathrm{p}<0.05$ was considered to statistically significan.

\section{RESULTS}

A total of 503 patients were admitted to the ICU, patients under 65 years of age were excluded from the study. Patient demographics and comorbidities are summarized in Table I. In total, I 47 patients aged $65-98$ years $(74.98 \pm 7.81$ years) were included in the study. Of the participating patients, 57 (38.8\%) were female and 90 (61.2\%) were male. While the statistical significance of the demographic data 
Table I. Demographic features of patients

\begin{tabular}{|c|c|c|c|c|}
\hline & Group I $(n=52)$ & Group $2(n=4 I)$ & Group $3(n=54)$ & $\mathbf{p}$ \\
\hline \multicolumn{5}{|l|}{ Gender, n (\%) } \\
\hline Female & $26(50.0)$ & $14(34.1)$ & $17(3 \mid .5)$ & $0.114^{k}$ \\
\hline Male & $26(50.0)$ & $27(65.9)$ & $37(68.5)$ & \\
\hline Age, mean $\pm S D$ & $80.21 \pm 6.61(80)$ & $74.66 \pm 5.5(74)$ & $70.19 \pm 7.28(67)$ & $0.001^{* \mathrm{~b}}$ \\
\hline \multicolumn{5}{|l|}{ Comorbidities, n (\%) } \\
\hline No & II (2I.2) & $7(17.1)$ & $5(9.3)$ & $0.23 I^{k}$ \\
\hline Yes (At least one) & 41 (78.8) & $34(82.9)$ & $49(90.7)$ & \\
\hline \multicolumn{5}{|l|}{ Hypertension, n (\%) } \\
\hline No & $24(46.2)$ & $17(45.5)$ & $23(42.6)$ & $0.916^{k}$ \\
\hline Yes & $28(53.8)$ & $23(57.5)$ & $31(57.4)$ & \\
\hline \multicolumn{5}{|l|}{ Diabetes mellitus, n (\%) } \\
\hline No & $35(67.3)$ & $30(75.0)$ & $35(64.8)$ & $0.56 I^{k}$ \\
\hline Yes & $17(32.7)$ & $10(25.0)$ & $19(35.2)$ & \\
\hline \multicolumn{5}{|c|}{ Cronic obstructive pulmonary disease, $\mathrm{n}(\%)$} \\
\hline No & $46(88.5)$ & $23(57.5)$ & $46(85.2)$ & $0.001^{* k}$ \\
\hline Yes & $6(11.5)$ & $17(42.5)$ & $8(14.8)$ & \\
\hline \multicolumn{5}{|c|}{ Coronary artery disease, n (\%) } \\
\hline No & $37(7 \mid .2)$ & $22(55.0)$ & $27(50.0)$ & $0.073^{k}$ \\
\hline Yes & $15(28.8)$ & $18(45.0)$ & $27(50.0)$ & \\
\hline
\end{tabular}

Table 2. Comparison time of extubation. the time of ICU mortality, discharge time and IMV requirement time of the intubated patients $(n=119)$

\begin{tabular}{|c|c|c|c|c|}
\hline & Group I $(n=43)$ & Group $2(n=35)$ & Group $3(n=4 I)$ & $\mathbf{p}$ \\
\hline Time of extubation $(\mathrm{h})$ & $120.0 \pm 43.89$ & $140.67 \pm 1 \mid 3.18$ & $230.83 \pm 103.92$ & $0.142^{\mathrm{a}}$ \\
\hline The time of ICU mortality $(\mathrm{h})$ & $110.1 \pm 95.15$ & $206.13 \pm 134.65$ & $|99.69 \pm| 45.8 \mid$ & $0.00 I^{* b}$ \\
\hline Discharge time $(\mathrm{h})$ & $154.38 \pm 46.53$ & $269.11 \pm 206.52$ & $244.39 \pm|21.7|$ & $0.191^{\mathrm{b}}$ \\
\hline IMV requirement time $(\mathrm{h})$ & $88.72 \pm 92.27$ & $173.86 \pm 130.14$ & $|75.88 \pm| 45.58$ & $0.00 I^{* b}$ \\
\hline
\end{tabular}

${ }^{a}$ One-Way ANOVA test: values are given as mean \pm standard deviation. ${ }^{b}$ Kruskal Wallis $\mathrm{H}$ test: values are given as mean \pm standard deviation. ${ }^{*}<0.05$ statistically significant. (h) Hour; ICU: Intensive care units; IMV: Invasive mechanical ventilation.

was similar between the three groups, the age parameter showed a statistically significant difference between the three groups $(p=0.00 I)$. In addition, the incidence of chronic obstructive pulmonary disease (COPD) was significantly higher in Group 2 compared to the other groups $(p=0.001)$.

A total of 119 patients were followed up on intubation, and the extubation times of these intubated patients were similar between the groups (I20.0 $\pm 43.89,140.67 \pm$ I I3.18, $230.83 \pm 103.92$ hours, respectively; $p=0.142$; Table 2 ). The duration of mechanical ventilation was the shortest in Group I with 88.72 \pm 92.27 hours, while the longest duration of mechanical ventilation was observed in Group 3 with $175.88 \pm 145.58$ hours.

No significant differences were detected when the groups were compared in terms of their CT scores (Table 3). In total, 108 patients died, but the mortality rates for the groups were similar. It was found that the patient age and respiratory status at the time of admission had a significant effect on the duration of mechanical ventilation (Table 4). In Group I, $25 \%(n=13)$ of the patients had survived at the end of the follow-up period, with a mortality rate of $75 \%$ $(n=39)$. In Group 2, it was determined that the rate of surviving patients was $19.5 \%(n=8)$ with a mortality rate of $80.5 \%(n=33)$ at the end of the follow-up period. In Group $3,33.3 \%(n=18)$ of the patients survived, but $66.7 \%(n=36)$ had died by the end of the follow-up period. The mean survival time was 6.43 days in Group I, II.2I days in Group 2 , and 10.18 days in Group 3 (Fig. I). A statistically significant difference was observed between the groups in terms of invasive mechanical ventilation (IMV) requirement time $(p=0.00 I)$ and the time of mortality in the ICU $(p=0.00 I)$.

\section{DISCUSSION}

In this retrospective cohort study, we found that mortality occurred significantly earlier in patients admitted to the 
Table 3. Comparison of computed tomography scores, intubation, extubation, mortality and discharge rates between groups

\begin{tabular}{|c|c|c|c|c|}
\hline & Group I $(n=52)$ & Group $2(n=4 I)$ & Group $3(n=54)$ & $\mathbf{p}$ \\
\hline \multicolumn{5}{|c|}{ Computed tomography, n (\%) } \\
\hline Mild & $20(38.5)$ & II (26.8) & $19(35.2)$ & $0.488^{k}$ \\
\hline Moderate-Severe & $32(6 \mid .5)$ & $30(73.2)$ & $35(64.8)$ & \\
\hline \multicolumn{5}{|c|}{ Respiratory status at admission, $\mathrm{n}(\%)$} \\
\hline Spontaneous & $40(76.9)$ & $29(70.7)$ & $48(88.9)$ & $0.079^{k}$ \\
\hline Intubated & $12(23.1)$ & $12(29.3)$ & $6(11.1)$ & \\
\hline \multicolumn{5}{|c|}{ Intubation at Intensive Care Units, n (\%) } \\
\hline No & $9(17.3)$ & $6(14.6)$ & $13(24.1)$ & $0.47 I^{k}$ \\
\hline Yes & $43(82.7)$ & $35(85.4)$ & $4 \mid(75.9)$ & \\
\hline \multicolumn{5}{|l|}{ Extubation, n (\%) } \\
\hline No & $47(90.4)$ & $38(92.7)$ & $48(88.9)$ & $0.823^{k}$ \\
\hline Yes & $5(9.6)$ & $3(7.3)$ & $6(11.1)$ & \\
\hline \multicolumn{5}{|l|}{ Mortality, n (\%) } \\
\hline No & $13(25.0)$ & $8(19.5)$ & $18(33.3)$ & $0.304^{k}$ \\
\hline Yes & $39(75.0)$ & $33(80.5)$ & $36(66.7)$ & \\
\hline \multicolumn{5}{|l|}{ Discharge, n (\%) } \\
\hline No & $39(75.0)$ & $32(78.0)$ & $36(66.7)$ & $0.423^{k}$ \\
\hline Yes & $13(25.0)$ & $9(22.0)$ & I8 (33.3) & \\
\hline
\end{tabular}

${ }^{k}$ Chi-square test: values are given as frequency (percentage). ${ }^{*}<<0.05$ statistically significant.

Table 4. Factors affecting mechanical ventilation treatment time

Tests of between-subjects effects

Dependent variable: Mechanical ventilation treatment time (hour)

\begin{tabular}{lcccc}
\hline Source & df & MeanSquare & F & Sig. \\
\hline Corrected model & 5 & 73776.404 & 5.157 & .000 \\
Intercept & I & 479721.440 & 33.531 & .000 \\
Gender & I & 2256.163 & .158 & .692 \\
Comorbidity & $\mathrm{I}$ & 9921.716 & .694 & .407 \\
CT scores & $\mathrm{I}$ & 17404.721 & 1.217 & .272 \\
Respiratory status & & & & \\
at admission & $\mathrm{I}$ & 121546.340 & 8.496 & .004 \\
Age & $\mathrm{I}$ & 285460.284 & 19.953 & .000 \\
Error & 113 & 14306.670 & & \\
Total & 119 & & & \\
Corrected total & 118 & & & \\
\hline
\end{tabular}

ICU with the diagnosis of COVID-19. However, no differences were seen between the three groups in terms of 28-day intensive care mortality.

In a previous study involving 1,043 patients, the mortality rate of COVID-19 patients over 64 was $36 \%$, whereas in younger patients it was only $15 \% .{ }^{[17]}$ There are several reasons for this increased risk in the elderly. For example, a recent meta-analysis demonstrated that elderly patients have the highest risk of death from both in seasonal and pandemic influenzas. ${ }^{[18]}$ In contrast, children and adolescents under the age of 18 had a significantly lower risk

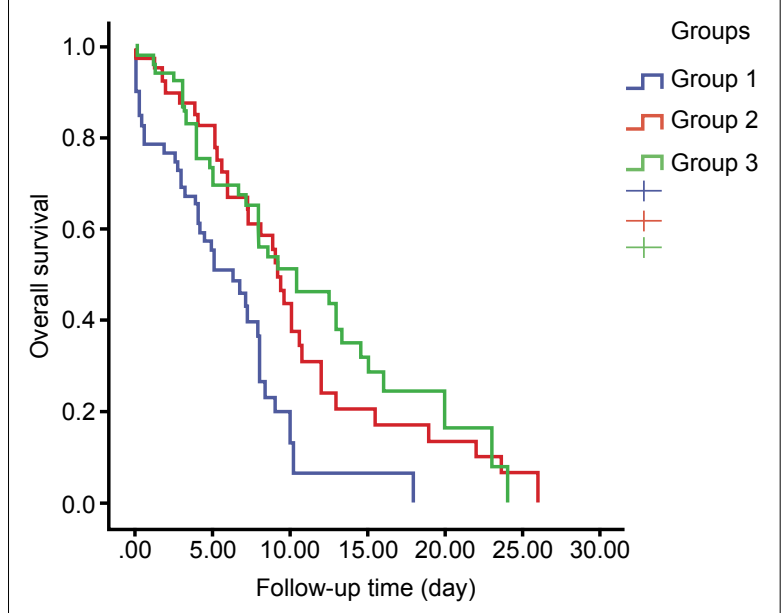

Figure 1. Overall survival according to groups.

of death during the pandemics compared to non-elderly adults. $^{[19]}$

Concomitant diseases such as hypertension (HT) and diabetes mellitus (DM) are among the most important causes of increased mortality in elderly patients. DM and hyperglycemia increase vascular inflammation and systemic oxidative stress, resulting in endothelial dysfunction. Specifically, DM has been reported to be associated with severe viral pneumonia and death. ${ }^{[20]}$ It can suppress the activity of natural killer $\mathrm{T}$ cells and reduce the number of CD3+ T cells. ${ }^{[21]}$ Therefore, the presence of DM is a predictive factor for viral infection. We found in our study that the rates of DM and HT were similar in both the treatment and control groups. 
The management of frail patients suffering from interstitial pneumonia caused by COVID-19 infection involves many additional challenges and is clinically complex. These patients are very susceptible to the risk of concomitant complications such as delirium, ARDS, bacterial superinfection, sepsis, and septic shock ${ }^{[2]}$ and such complications greatly increase the incidence of mortality. This study, however, revealed that an early treatment protocol cannot reduce mortality. We found that in the cohort of patients who died, mortality occurred earlier if treatment was not initiated after diagnosis, but the results were not statistically significant. A further dangerous situation faced by hospitals is the admission of patients with severe diseases such as late-stage myocardial infarction, heart failure, stroke, and fractures due to the additional fear of COVID-19 infection in the hospital. Delays in the treatment of patients with comorbidities are one of the main causes of the observed high mortality rates. In our study, although the clinical symptoms of COVID- 19 appeared in 52 patients, their treatment was not started immediately. This may have been due to the fact that after symptoms appeare; the patients preferred to stay under quarantine at home instead of visiting a hospital.

Whether HCQ is effective in treating COVID-19 is controversial. ${ }^{[23]}$ This compound has been found to inhibit lysosomal activity and autophagy, plays a role in membrane stability, and can affect various signaling pathways and transcriptional activity, ${ }^{[24]}$ leading to the inhibition of cytokine production. This study does not represent a randomized clinical trial, but instead reflects the real-life experience of intensive care professionals. Our results did not have the required power to reveal whether an HCQ treatment is effective when started earlier, and this is supported to some extent by conflicting reports from the literature. In the retrospective evaluation of I,06I cases with very low mortality and early initiation of combined therapy, these two agents (Azithromycin+HCQ) were declared to be safe in the treatment of COVID- $9^{[8]}$ In that study, $95 \%$ of the patients had a mild case of COVID- 19 at admission, and only $0.9 \%$ were monitored in the ICU.

A distinctive feature of our study was that all subjects were critically ill patients followed up in the ICU. The FDA recommends that HCQ should not be used generally except for critical patients or in registered clinical trials. [25] Similarly, our results support the view that early HCQ therapy had no additional benefit in severe COVID-19 cases requiring intensive care.

\section{Limitations}

The most important limitation of this study is that it represents a retrospective analysis. Therefore, a randomized controlled trials with larger samples of elderly patients are needed. Additionally, it was not possible to evaluate serum drug levels because of the intense pandemic period

\section{CONCLUSION}

The present study has revealed that early administration of HCQ sulfate had no significant effect on patient survival and outcome. The mortality rate, discharge rate, CT findings, intubation and extubation times did not differ between the treatment groups. But mortality occurred significantly earlier in patients who were admitted to the ICU with the diagnosis of COVID-19 but without a started treatment protocol. Therefore, according to the main results of our study, we cannot recommend pre-admission of HCQ treatment in critically ill geriatric patients with COVID-19.

\section{Ethics Committee Approval}

This study approved by the Kartal Dr. Lutfi Kirdar City Hospital Clinical Research Ethics Committee (Date: 08.07.2020, Decision No: 2020/5/4/181//6).

\section{Informed Consent}

Retrospective study.

Peer-review

Internally peer-reviewed.

Authorship Contributions

Concept: F.Ç., A.S., Y.B., E.B., K.S.; Design: F.Ç., A.S., Y.B., E.B., K.S.; Supervision: F.Ç., A.S., Y.B., E.B., K.S.; Materials: F.Ç., A.S.; Data: F.Ç., Y.B., E.B.; Analysis: A.S., Y.B.; Literature search: F.Ç., Y.B., E.B.; Writing: F.Ç., K.S.; Critical revision: F.Ç., K.S., E.B.

Conflict of Interest

None declared.

\section{REFERENCES}

1. Astuti I, Ysrafil. Severe acute respiratory syndrome coronavirus 2 (SARS-CoV-2): An overview of viral structure and host response. Diabetes Metab Syndr 2020;14:407-12. [CrossRef]

2. Koenig KL, Beÿ CK, McDonald EC. 2019-nCoV: The identify-isolate-inform (3I) tool applied to a novel emerging coronavirus. West J Emerg Med 2020;21:184-90. [CrossRef]

3. Guan WJ, Ni ZY, Hu Y, Zhou W, Wang LH, Cui XG. China medical treatment expert group for covid-19. Clinical characteristics of coronavirus disease 2019 in China. N Engl J Med 2020;30;382:1708-20.

4. Liu K, Chen Y, Lin R, Han K. Clinical features of COVID-19 in elderly patients: A comparison with young and middle-aged patients. J Infect 2020;80:e14-8. [CrossRef]

5. Lara PC, Nguyen NP, Macias-Verde D, Burgos-Burgos J, Arenas M, Zamagni A, et al. Whole-lung low dose irradiation for SARS-Cov2 induced pneumonia in the geriatric population: An old effective treatment for a new disease? Recommendation of the International Geriatric Radiotherapy Group. Aging Dis 2020;9;11:489-93.

6. Porcheddu R, Serra C, Kelvin D, Kelvin N, Rubino S. Similarity in case fatality rates (CFR) of COVID-19/SARS-COV-2 in Italy and China. J Infect Dev Ctries 2020;14:125-8. [CrossRef]

7. Magrone T, Magrone M, Russo MA, Jirillo E. Peripheral immunosenescence and central neuroinflammation: a dangerous liaison. A dietary approach. Endocr Metab Immune Disord Drug Targets. 2020;20:1391-411. [CrossRef]

8. Million M, Lagier JC, Gautret P, Colson P, Fournier PE, Amrane S, et al. Early treatment of COVID-19 patients with hydroxychloroquine 
and azithromycin: A retrospective analysis of 1061 cases in Marseille, France. Travel Med Infect Dis 2020;35:101738. [CrossRef]

9. El Mershati S, Thouvenin A, Secretan PH, De Lonlay P, Tuchman$\mathrm{n}$-Durand C, Cisternino $\mathrm{S}$, et al. Formulation and stability study of hydroxychloroquine sulfate oral suspensions. Pharm Dev Technol 2021;26:328-34. [CrossRef]

10. Liu J, Cao R, Xu M, Wang X, Zhang H, Hu H, et al. Hydroxychloroquine, a less toxic derivative of chloroquine, is effective in inhibiting SARS-CoV-2 infection in vitro. Cell Discov 2020;6:16. [CrossRef]

11. Yao X, Ye F, Zhang M, Cui C, Huang B, Niu P, et al. In Vitro antiviral activity and projection of optimized dosing design of hydroxychloroquine for the treatment of severe acute respiratory syndrome coronavirus 2 (SARS-CoV-2). Clin Infect Dis 2020;71:732-9. [CrossRef]

12. Andreani J, Le Bideau M, Duflot I, Jardot P, Rolland C, Boxberger $\mathrm{M}$, et al. In vitro testing of combined hydroxychloroquine and azithromycin on SARS-CoV-2 shows synergistic effect. Microb Pathog 2020;145:104228. [CrossRef]

13. WHO. Definition of an older or elderly person. Available at: http:// www.who.int/health info/survey/ageing folder/in/index.html. Accessed Jun 12, 2010.

14. Singh S, Bajorek B. Defining 'elderly' in clinical practice guidelines for pharmaco therapy. Pharm Pract (Granada) 2014;12:489. [CrossRef]

15. Republic of Turkey Ministry of Health: Covid-19 (SARS-CoV infection-2) Science Board Study Guide. Available at: https://covid19bilgi.saglik.gov.tr/tr/covid-19-rehberi.html. Accessed Aug 4, 2021.

16. Wong CK, Lai V, Wong YC. Comparison of initial high resolution computed tomography features in viral pneumonia between metapneumovirus infection and severe acute respiratory syndrome. Eur J Radiol2012;81:1083-7. [CrossRef]
17. Grasselli G, Zangrillo A, Zanella A, Antonelli M, Cabrini L, Castelli A, et al. Baseline characteristics and outcomes of 1591 patients infected with SARS-CoV-2 admitted to ICUs of the Lombardy Region, Italy. JAMA 2020;323:1574-81. [CrossRef]

18. Mertz D, Kim TH, Johnstone J, Lam PP, Science M, Kuster SP, et al. Populations at risk for severe or complicated influenza illness: systematic review and meta-analysis. BMJ 2013;347:f5061. [CrossRef]

19. Sinha IP, Harwood R, Semple M G, Hawcutt DB, Thursfield R, Narayan O, et al. COVID-19 infection in children. Lancet Respir Med 2020;8:446-7. [CrossRef]

20. Liu H, Chen S, Liu M, Nie H, Lu H. Comorbid chronic diseases are strongly correlated with disease severity among COVID-19 patients: A systematic review and meta-analysis. Aging Dis 2020;11:668-78.

21. Van den Brand JM, Smits SL, Haagmans BL. Pathogenesis of Middle East respiratory syndrome coronavirus. J Pathol 2015;235:175-84.

22. Boccardi V, Ruggiero C, Mecocci P. COVID-19: A geriatric emergency. Geriatrics (Basel) 2020;5:24. [CrossRef]

23. Celotto S, Veronese N, Barbagallo M, Ometto F, Smith L, Pardhan $\mathrm{S}$, et al. An umbrella review of systematic reviews with meta-analyses evaluating positive and negative outcomes of Hydroxychloroquine and chloroquine therapy. Int J Infect Dis 2021;103:599-606. [CrossRef]

24. Schrezenmeier E, Dörner T. Mechanisms of action of hydroxychloroquine and chloroquine: implications for rheumatology. Nat Rev Rheumatol 2020;16:155-66. [CrossRef]

25. FDA. FDA Drug Safety Communication: FDA cautions against use of hydroxychloroquine or chloroquine for COVID-19 outside of the hospital setting or a clinical trial due to risk of heart rhythm problems. Available at: https://www.fda.gov/media/137250/download. Accessed May 7, 2020.

\section{Geriatrik Hastalarda Kabul Öncesi Hidroksiklorokin Tedavisinin COVID-19 ile İlişkili Yoğun Bakım Takibi Üzerine Etkisi}

Amaç: Geriatrik hastalarda yoğun bakım ünitelerine kabul oranları ve ölüm oranları, COVID- 19 enfeksiyonu olan popülasyonun geri kalanından daha yüksektir. Hidroksiklorokin sülfatın etkinliği artık kabul edilmiş olmasına rağmen, özellikle enfeksiyon sırasında erken başlandığında, geriatrik hastalarda bu erken zaman noktalarında etkinliği araştırılmamıştır. Bu çalışmada birincil amacımız, hidroksiklorokin sülfatın erken tedavisinin COVID-19 pozitif geriatrik hastalarda klinik semptomlara dayalı olarak, yoğun bakım öncesi ve hasta sağkalımı üzerindeki etkilerini araştırmaktı.

Gereç ve Yöntem: Yoğun bakım ünitesinde COVID-I9 tanısı alan toplam I47 geriatrik hasta üç gruba ayrıldı: Acil servisten yoğun bakım ünitesine kabul edilen ancak tedavi almayan hastalar (Grup I); beş günlük tedavi başlatılan ancak tamamlanmayan klinikten kabul edilen hastalar (Grup 2); ve beş günlük ilaç tedavisini tamamlamış olanlar (Grup 3).

Bulgular: Üç grup arasında demografik veriler benzer olmasına rağmen, yaş parametreleri aralarında önemli ölçüde farklıydı. Ayrıca ölüm oranı, taburculuk veya ekstübasyon zamanı açısından gruplar arasında fark yoktu. Grup I'de mortalite süresi ve mekanik ventilasyon süresi anlamlı olarak daha kısa bulundu $(\mathrm{p}=0.00 \mathrm{I})$.

Sonuç: Hidroksiklorokin sülfatın erken uygulanmasına dayalı olarak, hasta sağkalımı ve sonucu üzerinde önemli bir etki görülmemiştir. Ana bulgularımıza göre, bu çalışma COVID- I'u olan geriatrik kritik hastalarda başvuru öncesi hidroksiklorokin tedavisi önermemektedir.

Anahtar Sözcükler: Geriatri; hidroksiklorokin; koronavirüs; mortalite; yoğun bakım üniteleri. 